\title{
Pengaruh Desain Stent pada Jumlah Limfosit dan Trombosit Kelinci (Oryctolagus Cuniculus)
}

\section{The Influence of Stent Design Towards the Number of Lymphocytes and Platelets in Rabbit (Oryctolagus Cuniculus)}

\author{
*Widowati Siswomihardjo dan Dyah Anindya Widyasrini \\ Sekolah Pascasarjana, Universitas Gadjah Mada \\ Departemen Ilmu Bahan Kedokteran Gigi, Fakultas Kedokteran Gigi, \\ Universitas Gadjah Mada \\ Yogyakarta, Indonesia \\ Email: dyah.anindya@gmail.com
}

\author{
Dinar Arifianto \\ Departemen Patologi Klinik, Fakultas Kedokteran Hewan, Universitas Gadjah Mada \\ Yogyakarta, Indonesia \\ Email: dinar.arifianto@ugm.ac.id
}

\section{Setyo Budhi}

Departemen Ilmu Bedah dan Radiologi, Fakultas Kedokteran Hewan,

Universitas Gadjah Mada

Yogyakarta, Indonesia

Email: setyobudi@ugm.ac.id

\section{Nahar Taufiq}

Departemen Kardiologi dan Vaskuler, Fakultas Kedokteran, Universitas Gadjah Mada

Yogyakarta, Indonesia

Email: nahar@ugm.ac.id

Submitted: 15-11-2019; Revised: 21-11-2019; Accepted: 21-11-2019

\begin{abstract}
Percutaneous Coronary Intervention (PCI) is an effective treatment for coronary artery diseases. For the procedure, a stent is put in the coronary arteries. There are a variety of stent materials and designs available on the market. The development of stents continues with the goal to reduce the risk of failure. The design and the ability of the stent as a vascular scaffold are important factors for the success of the stent. The implantation of a stent as a foreign body can lead to inflammation. In general, the inflammation is characterized by an increased number of lymphocytes. Then, platelets play a role in coordinating the occurrence of inflammation and immune response. This
\end{abstract}

*Corresponding author: widowati@ugm.ac.id.

Copyright @ 2019 THE AUTHOR(S). This article is distributed under a Creative Commons Attribution-Share Alike 4.0 International license. Jurnal Teknosains is published by the Graduate School of Universitas Gadjah Mada. 
study aims to determine the effect of stent design on the number of lymphocytes and platelets as a marker of inflammation. The study was conducted on ten rabbits divided into two treatment groups, namely KP1 (new design stent) and KP2 (commercial stent) by placing a stent on the iliac artery. One hour before stenting, 2 $\mathrm{ml}$ of blood was collected in all experimental animals. Then, $2 \mathrm{ml}$ of blood was collected again on the 7th and 28th day after stenting. Data was collected based on the number of lymphocytes and platelets from all experimental animals. Statistical analysis using twoway ANOVA shows no significant difference ( $p>0.05)$ on the number of lymphocytes and platelets between the two groups with different stent designs. It can be concluded that the design of a stent does not show a tendency to cause inflammation.

Keywords: Design; Inflammation; Lymphocytes; Platelets; Stent.

\footnotetext{
ABSTRAK

Intervensi koroner perkutan (PCI) merupakan cara perawatan yang efektif untuk penyakit arteri koroner. Prosedur ini dilakukan dengan cara memasang stent dalam pembuluh darah arteri koroner. Berbagai bahan dan desain stent tersedia di pasaran. Pengembangan stent terus dilakukan untuk mengurangi risiko kegagalan. Desain stent serta kemampuan stent sebagai perancah vaskuler merupakan faktor penting bagi keberhasilan stent. Pemasangan stent sebagai proses implantasi benda asing dapat memicu terjadinya inflamasi. Secara umum inflamasi ditandai dengan adanya jumlah limfosit yang meningkat. Sedangkan trombosit berperan untuk mengkoordinasi terjadinya inflamasi dan respons imun. Tujuan penelitian ini adalah untuk mengetahui pengaruh desain stent terhadap jumlah limfosit dan trombosit sebagai penanda terjadinya inflamasi. Penelitian dilakukan pada 10 ekor kelinci yang dibagi menjadi 2 kelompok perlakuan, yaitu KP1 (stent desain baru) dan KP2 (stent komersial) dengan memasang stent pada arteri iliaka. Satu jam sebelum pemasangan stent, dilakukan pengambilan $2 \mathrm{ml}$ darah pada semua hewan coba. Pengambilan $2 \mathrm{ml}$ darah dilakukan kembali pada semua hewan coba, yaitu pada hari ke-7 dan ke-28 setelah pemasangan stent. Penghitungan data berupa jumlah limfosit dan trombosit dari semua hewan coba. Hasil analisis statistik dengan menggunakan ANAVA dua jalan menunjukkan tidak ada perbedaan yang bermakna $(p>0,05)$ terhadap jumlah limfosit dan trombosit di antara kedua kelompok hewan coba
}

yang dipasang stent dengan desain yang berbeda, sehingga dapat disimpulkan bahwa desain tidak ada kecenderungan menimbulkan gejala inflamasi yang bermakna.

Kata Kunci: Desain; Iimfosit; Inflamas; Stent; Trombosit.

\section{PENGANTAR}

Intervensi koroner perkutan (PCI) merupakan metode perawatan yang dianggap efektif dan telah lama digunakan dalam perawatan penyakit arteri koroner obstruktif (Balli dkk., 2015). Prosedur PCI bertujuan untuk mengembalikan kemampuan lumen arteri koroner yang menyempit akibat proses atherosklerotik (Cannon dkk., 2010). Prosedur ini dilakukan dengan cara pemasangan stent dalam pembuluh darah arteri koroner (Borhani dkk., 2018).

Secara umum, stent merupakan implant tubuler yang mirip pipa kecil dengan jaringjaring (strut) untuk memberikan kekuatan mekanis arteri stenotik sehingga risiko penutupan arteri dapat dihilangkan (Borhani dkk., 2018). Prosedur pemasangan stent banyak menjadi pilihan karena dilakukan tanpa perlu dilakukan pembedaan jantung (Levesque dkk., 2004). Pada prosedur PCI, bagian arteri koroner yang menyempit akan melebar setelah diberikan tekanan dengan kekuatan tertentu melalui balon kateter. Adapun balon kateter ditempatkan pada dinding stenotik melalui proses angioplasti. Stent berfungsi untuk mempertahankan lebar lumen setelah dilakukan angioplasti (Cannon dkk., 2010).

Setiap tahunnya hampir tiga juta stent diimplantasikan di seluruh dunia dan terus meningkat 6-7\% pertahun (Heleen dkk., 2010; Walker, 2015). Pada tahun 2012, terdapat lebih dari 1000 pasien di RSUP Dr. Sardjito Yogyakarta yang mendapatkan terapi melalui prosedur $\mathrm{PCI}$, termasuk penggunaan balon kateter dan pemasangan stent. Jumlah pasien yang memerlukan penggunaan stent mungkin akan terus meningkat, seiring dengan jumlah prevalensi kasus penyakit jantung di Indonesia yang tampak tidak ada penurunan berdasarkan hasil Riset Kesehatan Dasar stent tahun 2013 dan 2018 (Riskesdas, 2013; Riskesdas, 2018). 
Saat ini, berbagai bahan dan desain stent berbasis metal telah tersedia di pasaran. Pada dasarnya metal mudah mengalami korosi (Hermawan dkk., 2011) yang dapat berpengaruh terhadap biokompatibilitas bahan. Akan tetapi, penelitian secara in vitro menyebutkan bahwa SS 316L dan CoCr 605L sebagai bahan yang sering digunakan sebagai stent tidak menunjukkan indikasi terjadinya toksisitas (Siswomihardjo dkk., 2017). Selain itu bahan biodegradable juga telah dikembangkan sebagai material stent (Kozuh dkk., 2007; Song dkk., 2011). Beberapa logam stent yang ada di pasaran, maka cobalt chromium $(\mathrm{CoCr})$ merupakan jenis aloi yang banyak digunakan. Salah satu keungulan dari CoCr karena mudah dibentuk menjadi sangat tipis (Kereiakes dkk., 2003), selain itu tidak mudah terpengaruh oleh gelombang magnetik (Gul dan Masood, 2008).

Pengembangan stent terus dilakukan, khususnya untuk mengurangi risiko terjadinya in-stent restenosis dan trombosis. Desain stent dan kemampuan stent sebagai perancah vaskular merupakan faktor yang penting dalam keberhasilan stent (Kolandaivelu dan Rikhtegar, 2016). Selain itu, desain stent juga berpengaruh terhadap kekuatan dan ketahanannya saat dilakukan proses inflasi (Tontowi dkk., 2015). Stent perlu didesain untuk memiliki fleksibilitas yang baik agar dapat mengakomodasi lengkungan dan sudut dari pembuluh darah. Fleksibilitas yang baik juga diperlukan untuk mengurangi tegangan antara stent dan jaringan setelah dilakukan inflasi (Beule, 2008). Hal ini memperjelas bahwa desain mungkin dapat menimbulkan adanya luka pada pembuluh darah yang akan memicu terjadinya proses inflamasi.

Pemasangan stent merupakan proses implantasi suatu benda asing dalam tubuh. Inflamasi dapat terjadi dalam hitungan beberapa menit karena adanya iritasi benda asing baik internal maupun eksternal (Ahmed, 2011). Pada inflamasi akut biasa terjadi sampai kurang lebih satu minggu setelah implantasi, dan dapat berlanjut menjadi inflamasi kronis jika stimulus inflamasi tetap ada. Pada dasarnya interaksi antara material alat kesehatan dengan sel darah merupakan faktor yang sangat penting dalam menentukan keamanan pemakaiannya (Sunarintyas, dkk. 2017). Secara patofisiologi, sel darah mempunyai peran penting terhadap terjadinya inflamasi (Gasparyan dkk., 2019). Terdapat beberapa tanda pada peristiwa inflamasi, antara lain adalah jumlah sel leukosit total dan trombosit (Hartono dkk, 2015; Gasparyan dkk., 2019), yang menunjukkan adanya peningkatan jumlahnya (Farhangi, 2013). Kelinci (Oryctolagus cuniculus) memiliki mekanisme inflamasi dan pertahanan infeksi yang sedikit berbeda dengan manusia. Perubahan jumlah leukosit total pada kelinci dipengaruhi oleh perubahan jumlah limfosit karena limfosit merupakan komponen leukosit total terbanyak kelinci (Moore dkk., 2010).

Secara umum, inflamasi kronis dicirikan dengan adanya sel limfosit. Hal tersebut karena limfosit merupakan sel utama yang terlibat dalam reaksi imun dan merupakan mediator kunci dalam produksi antibodi serta respons alergi. Inflamasi kronis dengan limfosit yang cukup dominan biasanya berhubungan dengan toksisitas atau infeksi. Proses inflamasi kronis akibat benda asing atau biomaterial yang didominasi dengan adanya limfosit, dapat berakhir kurang dari dua minggu, atau dapat bervariasi tergantung tipe dan lokasi implantasi (Anderson, 2015). Sedangkan trombosit memiliki peran penting dalam mengkoordinasi terjadinya inflamasi dan respons imun. Trombosit dapat melepaskan berbagai mediator inflamasi yang dapat memodifikasi peran leukosit dan respons endotel sehingga akan menentukan derajat stimulus inflamasi (Thomas dan Storey, 2015). Penelitian ini bertujuan untuk mengevaluasi pengaruh stent dengan desain yang berbeda terhadap jumlah limfosit dan trombosit kelinci.

\section{Metode}

Penelitian telah disetujui oleh Komisi Etik untuk penelitian praklinik Laboratorium Penelitian dan Pengujian Terpadu Universitas Gadjah Mada Yogyakarta dengan nomor sertifikat 00030/04/LPPT/VI/2016. Penelitian menggunakan 10 ekor kelinci jenis Oryctolagus cuniculus jantan usia enam bulan dengan berat badan $3,5-4,5 \mathrm{~kg}$. Hewan coba dipelihara di 
Fakultas Kedokteran Hewan Universitas Gadjah Mada Yogyakarta dengan ditempatkan dalam kandang individu ukuran 70x50x50 cm. Setiap hari diberi pakan hijauan (sawi hijau, kangkung, bayam, lembayung, dan jagung) dan air minum ad libitum. Hewan coba dibagi menjadi dua kelompok, yaitu KP1 (kelompok perlakuan yang mendapat pemasangan stent desain baru) dan KP2 (kelompok perlakuan yang mendapat pemasangan stent komersial).

Semua kelinci dipuasakan terlebih dahulu selama 12 jam. Satu jam sebelum dimulai pemasangan stent, pada semua kelinci diambil darahnya melalui vena aurikula. Darah sebanyak $2 \mathrm{ml}$ ditampung dalam tabung darah dengan antikoagulan EDTA dan tanpa anti koagulan. Semua kelinci KP1 dan KP2 dicukur rambut di bagian medial femur dan daerah inguinal. Sebagai premedikasi kelinci diinjeksi dengan atropine sulfat dengan dosis $0,25 \mathrm{mg} /$ $\mathrm{kg}$ BB melalui sub kutan. Setelah 15 menit pasca injeksi premedikasi, kelinci diinjeksi dengan anestesi umum kombinasi Ketamin (dosis 35 $\mathrm{mg} / \mathrm{kg} \mathrm{BB}$ ) dan Xylazine (dosis $7 \mathrm{mg} / \mathrm{mg}$ BB) yang diinjeksikan secara intra muskuler.

Setelah teranestesi dengan sempurna, kateter intravena dipasang melalui vena auricula pada telinga kelinci sebagai tempat mengalirkan cairan infus $\mathrm{NaCl}$ fisiologis. Selanjutnya kelinci KP1 dan KP2 dibawa ke dalam ruang cath lab untuk dilakukan pemasangan stent.

Kelinci diberi suntikan premedikasi dan pembiusan secara IV. Setelah kelinci tersedasi secara optimal, kelinci diposisikan secara terlentang di meja cath lab, dengan kedua kaki dan tangan diikat. Kelinci diberi oksigen melalui nasal kanul. Setelah itu dilakukan prosedur septik-aseptik di daerah inguinal kanan dan kiri. Kemudian dilakukan akses arteri femoralis secara cut down. Dilakukan insersi sheat cathether yang dilanjutkan angiografi kontras dengan bantuan cathether JR ke dalam aorta abdominalis sampai terlihat arteri iliaka kanan dan kiri. Diameter aorta dan arteri iliaka komunis diukur berdasarkan hasil angiografi secara QCA.

Stent dengan berbahan dasar kobalt khromium ( $\mathrm{CoCr}$ ) dipasang di aorta abdo- minalis atau arteri iliaka komunis yang disesuaikan ukuran diameternya. Kemudian dilakukan angiografi ulang untuk melihat posisi stent yang terpasang. Sheat dilepas dan dilakukan penutupan luka bekas insersi dengan cara dijahit.

Selama lima hari pasca pemasangan stent, kelinci diinjeksi dengan antibiotik ampicillin. Selama itu juga diamati suhu tubuh kelinci setiap hari selama satu minggu untuk mengetahui adanya infeksi maupun reaksi penolakan terhadap stent yang dipasang. Pada hari ketujuh dan kemudian hari ke-28 setelah pemasangan stent, kembali diambil darah kelinci sebanyak $2 \mathrm{ml}$ untuk dihitung jumlah limfosit dan trombositnya.

\section{HASIL DAN PEMBAHASAN}

Reaksi terhadap implan dapat diukur dengan melihat transformasi limfosit (Teo dan Schalock, 2017). Secara deskriptif, tabel 1 menunjukkan bahwa terdapat perbedaan pada rerata jumlah limfosit baik pada kelompok dengan stent desain baru maupun stent komersial. Terlihat adanya penurunan pada hari ketujuh maupun hari ke-28 setelah pemasangan stent. Anderson (2013) menyebutkan adanya penurunan jumlah sel monosit, di mana limfosit termasuk di dalamnya, dari beberapa menit setelah implantasi biomaterial dan terus mengalami penurunan hingga beberapa hari sampai akhirnya stabil. Hal ini juga sesuai dengan pendapat Ahmed (2011) yang menyebutkan bahwa inflamasi dapat mulai terjadi dalam hitungan beberapa menit karena adanya iritasi benda asing baik internal maupun eksternal. Pada fase awal, limfosit sebagai bagian utama dari respons inflamasi ditekankan pada bagian neointima yang berbatasan langsung dengan strut stent, tetapi limfosit dapat ditemukan secara merata di seluruh segmen stent arteri yang lengkap (Grewe dkk., 2000). Nilai rerata limfosit dalam kurun waktu 0 hari hingga 28 hari menunjukkan nilai dalam rentang normal. Menurut Moore dkk. (2010), nilai rujukan limfosit kelinci normal adalah 1,375 - 6,5 ribu sel $/ \mu \mathrm{L}$. 
Widowati Siswomihardjo, Dyah Anindya Widyasrini, Dinar Arifianto, Setyo Budhi, dan Nahar Taufiq $\$$ Pengaruh Desain Stent pada Jumlah Limfosit dan Trombosit Kelinci ...

Tabel 1.

Rerata dan Standar Deviasi Jumlah Limfosit pada Hari Ke-0, 7, dan 28

\begin{tabular}{|c|c|c|c|c|c|c|}
\hline & \multicolumn{3}{|c|}{ KP1 (ribu sel/ $\mu \mathrm{L}$ ) } & \multicolumn{3}{|c|}{ KP2 (ribu sel/ $\mu \mathrm{L}$ ) } \\
\hline & 0 & 7 & 28 & 0 & 7 & 28 \\
\hline Rerata & 2.96 & 2.88 & 2.82 & 3.08 & 2.80 & 2.30 \\
\hline SD & 0.12 & 0.10 & 0.24 & 0.15 & 0.00 & 0.80 \\
\hline
\end{tabular}

Tabel 2.

Ringkasan Hasil ANAVA Dua Jalur Jumlah Limfosit pada Hewan Coba dengan Stent Baru

\begin{tabular}{|c|c|c|c|c|}
\hline & Df & Mean square & $\mathbf{F}$ & Sig. \\
\hline Corrected Model & 5 & 0,361 & 2,329 & 0,074 \\
\hline Intercept & 1 & 236,321 & 1526,295 & 0,000 \\
\hline Stent & 1 & 0,192 & 1,240 & 0,276 \\
\hline Hari & 2 & 0,537 & 3,470 & 0,047 \\
\hline Stent $*$ Hari & 2 & 0,268 & 1,731 & 0,199 \\
\hline
\end{tabular}

Tabel 3.

Rerata dan Standar Deviasi Jumlah Trombosit pada Hari Ke-0, 7, dan 28

\begin{tabular}{|c|c|c|c|c|c|c|}
\hline & \multicolumn{3}{|c|}{ KP1 (ribu/ $/ \mu \mathrm{L})$} & \multicolumn{3}{|c|}{ KP2 (ribu/ $/ \mu \mathrm{L})$} \\
\hline & 0 & 7 & 28 & 0 & 7 & 28 \\
\hline Rerata & 366.80 & 494.00 & 381.00 & 366.80 & 517.60 & 420.80 \\
\hline SD & 231.29 & 49.02 & 65.81 & 231.29 & 93.57 & 162.94 \\
\hline
\end{tabular}

Tabel 4.

Ringkasan Hasil ANAVA Dua Jalur Jumlah Trombosit pada Hewan Coba dengan Stent Baru

\begin{tabular}{|c|c|c|c|c|}
\hline & df & Mean square & $\mathbf{F}$ & Sig. \\
\hline Corrected Model & 5 & 22062,380 & 0,711 & 0,621 \\
\hline Intercept & 1 & 5406007,500 & 174,123 & 0,000 \\
\hline Stent & 1 & 3349,633 & 0,108 & 0,745 \\
\hline Hari & 2 & 52479,700 & 1,690 & 0,206 \\
\hline Stent $*$ Hari & 2 & 1001,433 & 0,032 & 0,968 \\
\hline
\end{tabular}

Kondisi yang sama terjadi pada hasil tabel 3 yang menunjukkan bahwa secara deskriptif terdapat perbedaan pada rerata jumlah trombosit, pada kelompok dengan stent desain baru dan dengan stent komersial. Dari hasil tersebut dapat dilihat bahwa setelah pemasangan stent ada kenaikan pada hari ketujuh yang diikuti dengan adanya penurunan pada hari ke-28. Akan tetapi, kenaikan dan penurunan nilai jumlah trombosit tersebut masih dalam rentang batas normal kelinci yaitu 304-656 ribu/ $\mu \mathrm{L}$ (Moore dkk., 2010).

Kenaikan jumlah trombosit pada hari ketujuh tersebut mungkin terjadi karena adanya reaksi pembentukan matriks sementara. Dalam beberapa detik setelah pemasangan implan, darah dari pembuluh yang rusak akan melingkupi material dan memulai adanya interaksi antara darah dengan implan. Dalam hitungan menit, komponen plasma host akan teradsorbsi pada permukaan implan secara spontan dan sangat cepat. Eksudat darah juga mengandung trombosit dan komponen koagulasi lain, yang akan membentuk jendalan darah untuk memberikan matriks sementara di sekitar material implan. Hal ini selanjutnya akan mengarah pada aktivasi dan agregasi trombosit. 
Protein komplemen yang teraktivasi setelah terjadi kontak dengan material implan, juga secara sinergis mendukung terjadinya adhesi dan aktivasi trombosit (Mariani dkk., 2019). Penurunan jumlah trombosit pada hari ke-28, mungkin menunjukkan jumlah yang mulai stabil. Stabilnya jumlah sel-sel pendukung neovaskularisasi menunjukkan adanya proses pembentukan jaringan granulasi yang merupakan respons penyembuhan dari jaringan yang diimplantasikan dengan biomaterial (Anderson, 2013).

Setelah stent dipasang, terjadi respons pembentukan lapisan baru pada dinding pembuluh darah. Lapisan lengkap stent pertama kali ditemukan 28 hari setelah implantasi. Lapisan neointima awal ini hampir memiliki struktur neomatriks, terdiri dari material trombotik dengan sel darah merah, agregat trombosit dan granulosit neutrofil. Empat minggu setelah augmentasi focal dari matriks ekstraseluler diamati di bagian-bagian dari dinding vaskular dikompresi oleh strut (Grewe dkk., 2000).

Terjadinya gejala inflamasi setelah pemasangan stent dapat dipahami karena strut, bagian dari desain stent, yang menempel pada dinding arteri koroner merupakan benda asing sehingga kemungkinan dapat memicu terjadinya respons inflamasi karena adanya trauma sistemik pada arteri (Gomes dan Buffolo, 2003). Berbagai karakteristik permukaan material yang diimplankan akan mempengaruhi tipe, jumlah, komposisi, dan terjadinya perubahan molekul yang teradsorbsi, kemudian menginisiasi terjadinya rekrutmen dan adhesi sel-sel inflamasi, sel darah, sel stromal, dan sel dari jaringan dalam hitungan jam hingga hari. Selanjutnya, akan diikuti dengan terjadinya respons inflamasi akut dan kronis. Intensitas respons inflamasi kronis tersebut akan dipengaruhi dengan besarnya kerusakan akibat proses implantasi dan material yang diimplankan itu sendiri, satunya akibat sifat fisik benda asing yang diimplankan (Mariani dkk., 2019; Anderson, 2013). Pada pemasangan stent, inflamasi terpusat pada titik dengan tekanan tertinggi dari struktur metal stent pada dinding arteri (Gomes dan Buffolo,
2003). Oleh karena itu, desain stent mungkin dapat berpengaruh dalam intensitas dan durasi terjadinya inflamasi.

Hasil pada tabel 2 menunjukkan bahwa tidak ada perbedaan signifikan pada jumlah limfosit antara kelompok dengan stent baru maupun stent komersial, tetapi terdapat perbedaan jumlah limfosit yang signifikan antara hari ke-0, 7, dan 28. Hal ini dapat dijelaskan bahwa perbedaan jumlah limfosit yang signifikan tersebut mungkin terjadi karena limfosit lebih banyak ditemukan pada lapisan neointima, sehingga limfosit dikirim dari sirkulasi untuk menuju ke jaringan yang baru terbentuk (Grewe dkk., 2000). Hal tersebut mengakibatkan adanya penurunan limfosit sirkulasi, tetapi penurunan yang terjadi masih dalam batas normal. Tabel 4 menunjukkan bahwa ternyata secara statistik perubahan jumlah trombosit setelah pemasangan stent tidak bermakna baik antara kelompok stent baru dan stent komersial maupun antarhari penilaian. Hal ini menunjukkan tidak adanya respons inflamasi yang berlebihan terjadi karena proses pemasangan stent, baik dengan desain stent baru maupun komersial. Nilai limfosit dan trombosit yang masih dalam batas rentang normal meyakinkan bahwa intensitas inflamasi yang diakibatkan dari proses pemasangan stent, material stent serta desain stent cenderung kecil, sehingga stimulus inflamasi tidak terjadi terus-menerus dan menuju ke arah penyembuhan pada hari ke-28. Desain dari stent kemungkinan tidak memberikan pengaruh terhadap terjadinya perubahan jumlah trombosit dalam inflamasi.

\section{SIMPULAN}

Dari pemeriksaan yang telah dilakukan, jumlah limfosit dan trombosit dua kelompok perlakuan tidak menunjukkan adanya perbedaan yang bermakna. Hal tersebut dapat dikatakan bahwa desain stent tidak menunjukkan pengaruh terhadap kemungkinan terjadinya inflamasi. Pada penelitian selanjutnya, perlu dilakukan pemeriksaan gambaran secara histologis dari jaringan yang terpapar stent. 


\section{UCAPAN TERIMAKASIH}

Kepada semua anggota tim riset Ina-stent yang sudah membantu pelaksanaan uji pada hewan coba kelinci. Juga kepada Kemristek Dikti untuk pemberian dana riset melalui kontrak nomer 4094/UN1-PIII/LT/DITLIT/2016.

\section{DAFTAR PUSTAKA}

Ahmed, A.U. (2011). An Overview of Inflammation: Mechanism and Consequences. Frontiers in Biology, 6(4): 274-281.

Anderson, J. dan Cramer, S. (2015). Perspectives on the Inflammatory, Healing, and Foreign Body Responses to Biomaterials and Medical Devices. Host Response to Biomaterials. Philadelphia: Elsevier.

Anderson, J.M. (2013). Inflammation, Wound Healing, and the ForeignBody Response. Biomaterials Science. Cambridge: Academic Press.

Balli M, Taşolar H, Çetin M, Cagliyan CE, Gözükara MY, Yilmaz M, Elbasan Z, dan Cayli M. (2015). Relationship of Platelet Indices with Acute Stent Thrombosis In Patients with Acute Coronary Syndrome. Postepy Kardiol Interwencyjnej., 11(3): 224-9.

Beule, M.D. (2008). "Finite Element Stent Design", Thesis, Belgium: Ghet University.

Borhani, S., Hassanajili, S., Ahmadi, T.S.H, dan Rabbani, S. (2018). Cardiovascular Stents: Overview, Evolution, and Next Generation. Progress in Biomaterials. 7(3): 175-205.

Cannon, A.L., Hood, L.K., dan Yakubov, J.S. (2010). Does the Metal Matter?. Cardiac Intervention Today. May/ June: 41-47

Gasparyan, A.Y., Ayvazyan, L., Mukanova, U., Yessirkepov, M., Kitas, G.D. (2019). The Platelet-to-lymphocyte Ratio as an Inflammatory Marker In
Rheumatic Diseases. Ann Lab Med. 39: 345-357.

Gomes, W.J. dan Buffolo, E. (2003). Coronary Stenting and Inflammation. Brazilian Journal of Cardiovascular Surgery. 18(4): III-VII.

Grewe, P.H., Deneke, T., Machraoui, A., Barmeyer, J., dan Mu"ller, K.M. (2000). Acute and Chronic Tissue Response to Coronary Stent Implantation: Pathologic Findings in Human Specimen. Journal of the American College of Cardiology, 35(1): 157-163.

Gul, I.H. dan Maqsood, A. (2008). Structural, Magnetic and Electrical Properties of Cobalt Ferrites Prepared by the SolGel Route. J of Alloys and Compounds. Vol 465: 227-31.

Heleen, M.M, van Bausekom, dan Patrick, W.S. (2010). Drug-eluting Stent Endothelium Presence or Dysfunction. JACC: Cardiovascular Intervention. 3: 76-77.

Hermawan, H., Ramdan, D. dan Djuansjah, J. (2011). "Metals for Biomedical Applications, Biomedical Engineering - From Theory to Applications". InTech. Diakses pada 2 September 2019. Dapat diakses di http://www.intechopen.com/ books/biomedical-engineeringfrom-theory-toapplications/metalsfor biomedicalapplications.

Kementerian Kesehatan RI. (2013). Riset Kesehatan Dasar. Jakarta: Badan Penelitian dan Pengembangan Kesehatan.

Kementerian Kesehatan RI. (2018). Riset Kesehatan Dasar. Jakarta: Badan Penelitian dan Pengembangan Kesehatan.

Kereiakes, D.J., Cox, D.A., Hermiler, J.B., Midei, M.G., Bacchinsky, W.B., Nukita, E.D., Leon, M.B., Finks, S., Marin, L., dan Lansky, A.J. (2003). Usefulness of a Cobalt 
Chromiumcoronary Stent Alloy. American Journal of Cardiology. Vol 92 : 463-66.

Kolandaivelu, K. dan Rikhtegar, F. (2016). The Systems Biocompatibility of Coronary Stenting. Interventional Cardiology Clinics. 5(2016): 295-306.

Kozuh, S., Gojic, M., dan Kosec, L. (2007). The Effect of Annealing on Properties of AISI 316L Base and Weld Metals. RMZ - Materials and Geoenvironment. 54:331-344.

Levesque, J., Dube, D., dan Fiset, M. (2004). Materials and Properties of Coronary Stent. Advanced Materials and Processes. 162(9): 45-48.

Mariani, E., Lisignoli, G., Borzi R.M., dan Pulsatelli, L. (2019). Biomaterials: Foreign Bodies or Tuners for the Immune Response?. International Journal of Molecular Science. 20(3): 636.

Moore, D.M., Zimmermen, K., Smith, S. A. (2015). Hematological Assessment in Pet Rabbits Blood Sample Collection and Blood Cell Identification. Veterinary Clinics of North America: Exotic Animal Practice, 18(1): 9-19.

Siswomihardjo W., Herliansyah MK., Dinar N. (2017). Biocompatibility of Metal Alloys as Medical Devices. Proceeding of 5th Int Conference on Instrumentation, Communications, Information Technology, and Biomedical Engineering (ICICI-BME), IEEE Publication, Bandung, 10-12.
Song, R.B., Xiang, J.Y., dan Hou, D.P. (2011). Characteristics of Mechanical Properties and Microstructure for 316L Austenitic Stainless Steel. Journal of Iron and Steel Research, Internatinal, 18(11): 53-59.

Sunarintyas, S., Siswomihardjo, W., Taufik, N., dan Bayu, Yosaphat. (2017) The Influence of $\mathrm{CoCr}$ L605 Induction to Blood Haemocompatibility. Proceeding of 5th Int Conference on Instrumentation, Communications, Information Technology, and Biomedical Engineering (ICICI-BME), IEEE Publication, Bandung, 10-12.

Teo, W.Z.W. dan Schalock, P.C. (2017). Metal Hypersensitivity Reactions to Orthopedic Implants. Dermatology and Therapy, 7:53-64.

Thomas, M.K. dan Storey, R.F. (2015). The Role of Platelets in Inflammation. Thrombosis and Haemostasis, 114(3): 449-458.

Tontowi, A.E., Pratama, I., Hariawan, H., Rinastiti, M., dan Siswomihardjo, W. (2015). Strength and Displacement of Open Cell Design of Coronary Stent in Responding of Various Inflated Pressure. $4^{\text {th }}$ International Conference on Instrumentation, Communication, Information Technology, and Biomedical Engineering (ICICI-BME), Bandung, 18-21.

Walker, C.M. (2015). How to Approach InStent Restenosis, NCVH $16^{\text {th }}$ Annual Conference, New Orleans. 